\title{
Chromosomal Disturbances during Mitotic Activity of Root Tip Cells in Allium by Certain Commonly Used Antibiotics
}

\author{
Sanjay Kumar
}

\section{Sanjay Kumar}

Department of Botany, Banaras Hindu University, Varanasi-221005, Uttar Pradesh, INDIA.

\section{Correspondence}

\section{Sanjay Kumar}

Department of Botany, Banaras Hindu University, Varanasi 221005, Uttar Pradesh, INDIA.

Phone No: 9436607170

E-mail: ksanjay79@gmail.com

\section{History}

- Submission Date: 09-10-2017;

- Review completed: 20-11-2017;

- Accepted Date: 18-12-2017

DOI : 10.5530/pj.2018.2.60

Article Available online http://www.phcogj.com/v10/i2

\section{Copyright}

(c) 2018 Phcog.Net. This is an openaccess article distributed under the terms of the Creative Commons Attribution 4.0 International license.

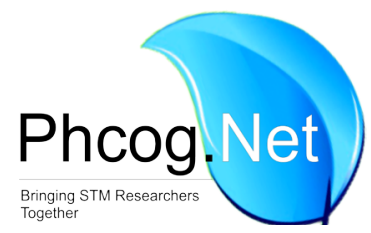

\begin{abstract}
Introduction: The certain commonly used antibiotics (cefixime, metronidazole, ciprofloxacin, cefpodoxime and cetirizine) purchased from the chemist shop in Mokokchung town, Nagaland and effects on mitotic activity of root tip meristematic cells of Allium Cepa were observed. Methods: The different concentrations were prepared by retaining the original effective concentrations $(400,400,500,200$ and $10 \mathrm{mg}$ ) of the antibiotics and treated the root tips of Allium at different times $(6,12$ and $24 \mathrm{~h})$ to record the effects or abnormalities. Results: All the concentrations (ppm) and time (h) were effective to induce the chromosomal disturbances during the mitotic activity of root tip cells in Allium. Conclusion: The mean value $( \pm$ S.E.) recorded for mitotic cells, mitotic stages, physiological and clastogenic abnormalities and showed a mixed response which could not predict dose response curve in actual.

Key words: Allium cepa, Antibiotics, Chromosomal disturbances, Physiological disturbances, Clastogenic abnormalities.
\end{abstract}

\section{INTRODUCTION}

Antibiotics or antibacterial are the anti-microbial drugs used for the prevention (growth inhibition) and treatment (killing of bacteria) of the bacterial infections. The broad-spectrum antibiotics administered based on the signs and symptoms of the patient for prevention of pathogen, when pathogen has not been identified and laboratory results may take several days to identify the pathogen which is also known as empirical therapy. ${ }^{1}$ The narrow spectrum antibiotics are administered to the patients, when pathogen has been already identified and known as definitive therapy. ${ }^{2}$ The broad spectrum antibiotics were so famous and easily available to the common people that without consultant of medical practitioner used by them. They consult only for the definitive therapy. A list of antibiotics is available at registered pharmacy in the market for different ailments caused by microbes. The antibiotics such as Chloroquine, Primaquine, Quinacrine, Chloramphenicol, Ciprofloxacin, Pyrimethamine, Dapsone, Mefloquine, Artemisinin, Trimethoprim, Antihistamines, atenolol, 3-Mix antibiotics, Metronidazole, Alprazolum, Antitumor antibiotics, Plant extract and Agricultural antibiotics were reviewed and discussed their uses and side effects on animal models, human beings and plants in the following paragraphs.

A review was done on the genotoxic potential of commonly used antimalarial drugs. ${ }^{3}$ A note on the control of malaria was reported. ${ }^{4}$ The drug chloroquine used in the treatment of malaria. The cytological effects of chloroquine were reported on the root meristem of Allium Cepa. ${ }^{5}$ The chloroquine genotoxicity was reported on the liver cells of Rat. ${ }^{6}$ The low dose radiation and vitamin $\mathrm{C}$ treatment was analysed on the chloroquine induced genotoxicity in mice. ${ }^{7}$ It was reported that chloroquine has capability to unite with DNA and intercalates with guanine of dsDNA. The attachment with DNA and intercalation of chloroquine with guanine residue in dsDNA causes conformational change in the DNA topology which makes the drug (chloroquine) a possible mutagenic agent.

Primaquine used to treat malaria at early stage of development of Plasmodium falciparum in the liver. But, Primaquine primarily used to treat liver reservoirs or hypnozoites of $P$. vivax and $P$. ovale. The drug primaquine induced the differential gene expression in mice liver. ${ }^{8}$ The overdose of Primaquine caused glucose-6-phosphate dihydrogen deficiency in humans. The side effects such as muta-genotoxicity of primaquine, pentaquin and pamaquine had been reported on Salmonella typhimurium..$^{9,10,11,12}$

The antimalarial drug quinacrine is a derivative of acridine. The acridine derivatives were used as chemotherapeutic agents. ${ }^{13}$ The mutagenic potentiality of Quinacrine was evaluated and reported. ${ }^{14,15}$ The non-surgical female sterilant (Quinacrine dihydrochloride) induced dicentrics, rings and marker chromosomes in human peripheral blood lymphocytes. ${ }^{16}$ The upper limit of toxicity was evaluated in aberration assay using cytotoxicity and chromo- 
some aberrations. ${ }^{17}$ The high number of aberrations may be analysed using comet assay. ${ }^{18}$

The use of quinacrine as an antimalarial drug was suppressed by other antimalarial drug because it has shown some severe side effects such as cyto-geno-muta-clastotoxicity in Ames Samonella assay, mouse lymphoma assay, chromosome aberration test (dicentrics, ring configurations, translocations, inversions, marker chromosomes, haploid, polyploidy and endoreduplication), micronucleus test, effects on Chinese hamster ovary cells, frame shift mutation in Pneumococcus, human lymphocytes, Drosophila melanogaster, altered nuclear structure and RNA synthesis, rat lymphocytes, and altered nuclear metabolism. ${ }^{19,20,21}$ It is used now for the treatment of giardiasis, rheumatic diseases, anthelminthic and female sterilization.

Chloramphenicol (CAP) is a very much dynamic antibiotic with wide range actions. The wide range includes, especially the easy dispersion through the cells and tissues, also oozing out through the secretion pathway. Cytogenetic and haematological effects were observed in Calves after the application of antibiotic and dispersed broadly in the body because of non-ionized and extremely lipid-soluble nature of Chloramphenicol. ${ }^{22}$

The CAP inhibits the mitochondrial function and protein synthesis in eukaryotic cells. The inhibition of protein synthesis badly affects the immunoglobulin manufacture and production as well as cell reproduction, multiplication and development. The result causes tiredness and aplasia (failure of an organ or tissue to develop or to function normally) among humans and animals. The induction of leukemia had been observed after application of chloramphenicol in toads. The toxic side effects of CAP had been reported on the human bone marrow such as bone marrow depression (BMD) and bone marrow aplasia (BMA). The BMD was observed more commonly because it starts simultaneously along with the oral administration of the antibiotic, but reversible (over a period) and dose-dependent. The BMA was observed less common, because it occurs occasionally after the oral administration of the antibiotic, but irreversible (over a period) and becomes lethal. ${ }^{23}$ Chloramphenicol induced the haemotoxicity in guinea pig. Also, BMD had been reported in household animals. ${ }^{24}$

Ciprofloxacin (CFX) is a fluroquinolone antibiotic drug with broad spectrum antibacterial and effective microbicidal activity. The antibacterial drug ciprofloxacin was evaluated for its genotoxic effects. ${ }^{25}$ The antibacterial drug Ciprofloxacin increased the hepatic and lipid hydroperoxides level in mice. ${ }^{26}$ The genotoxic and cytotoxic effects of Ciprofloxacin were observed in Human lymphocytes. ${ }^{27}$ The antimicrobials quinolone showed genotoxic potentials using comet assay and micronucleus test. ${ }^{28}$ CFX antibiotic extended its effective range on urinary tract infections (UTI), g positive bacteria, bacterial topoisomerase II (DNA gyrase), bacterial DNA replication, repair, transcription, and other cellular functions because of this bacterial death occur. CFX antibiotic and its quinolone derivatives had many unfavourable and toxic consequences on central nervous system, cardiovascular system, biochemical and immunological changes in various cells, immunomodulatory effects on monocytes and macrophages, delay in cell cycle, sister chromatid exchange, unscheduled DNA synthesis, apoptosis, reproductive developmental toxicity, carcinogenicity, androtoxicity, phototoxicity and cyto-genotoxic effects on eukaryotic cells. The ciprofloxacin and roxithromycin caused apoptosis of T-cells. The immunomodulatory effects of Quinolones were reported. ${ }^{29}$

Pyrimethamine is a metabolically slow antibiotic and used for erythrocytic shizontocide, but it is less effective on the pre erythrocytic phase of Plasmodium falciparum. The adverse side effects of Pyrimethamine are megaloblastic anaemia and granulocytopenia at high doses. The megaloblastic anaemia results from inhibition of DNA synthesis during RBC production. When the DNA synthesis is disrupted, the cell cycle cannot progress from growth stage $G_{2}$ to mitosis (M) stage. The granulocytopenia is a marked decrease in number of granulocytes of white blood cells containing enzymes to digest microorganisms. The genotoxic effects of antimalarial drug Pyrimethamine was evaluated in mouse. ${ }^{30}$ The long duration exposure of pyrimethamine was investigated and reported the genotoxic effects in the bone marrow and toxicity of spermatogenesis mice. ${ }^{31,32}$ Pyrimethamine caused micronucleus induction in the hamster lung cells and bone marrow cells of mice and, dosedependent effects on abnormal sperms, less epidydimal sperm count, abnormal germ cells and genotoxicity in animal model mice. ${ }^{33,34,35}$

The combination (Pyremethamine+Sulfadoxin) is widely used for the treatment of $P$. falciparum resistant malaria. The use of the drug (fansidar a combination of Sulfadoxine-pyrimethamine) against resistant P. falciparum reported the cyto-genotoxic effects (micronucleus and sister chromatid exchange induction) of the drug on cultured human lymphocytes. ${ }^{36}$

Dapsone is used for the treatment of leprosy, dermatitis herpetiformis. ${ }^{37}$ The combination (Dapson+pyrimethamine) used for malaria treatment. The side effects of the drug reported such as haemolytic anaemia, methemoglobinemia, toxic hepatic effects, cytogenic effects, micronucleus, clastogenic effects in mouse. ${ }^{38}$

The antimalarial drug (Mefloquine) is a shizonticide, which causes skeleton and muscular malformations at higher concentration in animal models such as rats, mice and rabbits. ${ }^{39}$ The mefloquine had shown the potential for genotoxicity and mutagenicity. ${ }^{40}$ The other side effects of Mefloquine (dose dependent) includes cyto-genotoxicity, polymorphonuclear neutrophils, decrease in phagocytosis, muta-genotoxicity, sister chromatid exchange, chromosomal aberrations, and lymphocytopenia in animal models (rats, mice and rabbits). ${ }^{41,42}$

The derivatives of artemisinin (artemether and artesunate) are active components of Artimisia annua (herb sweet worm wood). The chemistry, biology and history of quinolines and artemisinin were studied and reported. ${ }^{43}$ The antimalarial drugs artesunate and artemether showed the cyto-genotoxicity, DNA damage, clastogenic effects, micronuclei induction, necrosis, apoptosis, gastric cell line cancer at higher dosage in animal model i.e. human lymphocytes and mice. ${ }^{44,45}$ The drug artemisinin induced apoptosis, blocks prostate cancer growth and cell cycle arrest. ${ }^{46,47}$ The chemical (anti-malarial trioxanes like artemisinin) mechanism of action and cytochrome p450 metabolism studies lead to the design of new anti-malarial peroxides. ${ }^{48}$

Trimethoprim is very close to the anti-malarial drugs, but it is not used for the treatment of malaria. It is most useful in the treatment of urinary tract infections (UTI). The antibiotic (Trimethoprim) produced cytotoxicity, genotoxicity and sensitivity in fish as well as mammalian cells. Cytotoxic and genotoxic effects of combination (Triclosan and Trimethoprim) were observed in hemocytes of zebra mussel. ${ }^{49}$ The cyto-genotoxicity of the drug using micronucleus and comet assay test, sister chromatid exchange, single cell gel electrophoresis (SCGE), apoptosis, lysosomal membrane stability test, were reported on fish, mammalian cells, human lymphocytes, zebra mussel hemocytes, mouse. ${ }^{50}$ Cyto-genotoxicity of the combination (Sulfamethoxazole + trimethoprim) such as micronucleus and DNA damage was reported in rats. ${ }^{51}$ The micronuclei formation was observed in nourished and malnourished rats after treatment with Trimethoprim + sulfamethoxazole. The antimalarial compound artesunate showed genotoxicity and cytotoxicity in the somatic cells of mice and human lymphocytes. ${ }^{52}$

The drugs (Montelukast and levocetirizine) also known as antihistamines were used to cure and manage the sensitive to allergy, affected rhinitis and asthma indications. Montelukast and levocetirizine wedged the allergens and histamine receivers which causes allergic reactions and 
asthmatic warning signs. The amalgamation of the drugs (Montelukast and levocetirizine) has been of good quality command over different kinds of allergies and asthmatic symptoms but the drawback of the drug includes the crossing of the placenta then into the foetus and embryo in the expectant women. ${ }^{53}$

The cytotoxic and antibacterial activity was evaluated using the combination of 3-antibiotics together. A 3-antibiotic combination (3Mix) is commonly exercised in endodontics for root canal disinfection and pulp revascularization trials. The cytotoxicity and antibacterial efficacy (dose and time dependent) of $3 \mathrm{Mix}$ antibiotic was higher as compared to the single dose antibiotic on cultured cells except Metronidazole. ${ }^{54}$ The dosedependent cytogenetic and metabolic effects on DNA synthesis and total cell protein of four antibiotics (benzylpenicillin, cefuroxime, dicloxacillin and erythromycin,) were reported on the cultured endothelial cells of human. ${ }^{55}$

The different Benzodiazepines showed mutagenic, genotoxicity and carcinogen toxicity activity. ${ }^{56}$ The oxazepam showed genotoxicity using micronucleus test. ${ }^{57}$ The Alprazolam and Lorazepam caused cytotoxicity. ${ }^{58}$ The alprazolam and clonazepam caused differential effects on immune system and blood vesels of albino rats.

Atenolol, (a beta blocker drug) replaced the propranolol. The drug (propranolol), generally, utilized for the control of hypertension (abnormally high blood pressure or a state of psychological stress), angina (severe chest pain or intense localized pain), tachycardia (abnormally rapid heart rate), and acute myocardial infarction (heart attack) by the physicians. ${ }^{59}$ Atenolol drug concentration ranged from $50-100 \mathrm{mg} /$ day orally and the half-life of the drug was observed as $10 \mathrm{~h} .{ }^{60}$ Atenolol absorbed speedily from the gut and highest concentration was observed in serum within $2-3 \mathrm{~h} .{ }^{61}$ Atenolol is hydrophilic in nature and therefore its metabolic activity is slow. The slow metabolic activity causes the drug to be available (50\%) in the circulatory system at any time. ${ }^{62}$ There were reports on the unfavourable side effects or unavoidable consequences such as hepatotoxicity (drug induced liver damage), lupus erythematosus (autoimmune inflammatory diseases), septal panniculitis (a condition of subcutaneous fat affecting the layer of adipose tissue), memory impairment (ability to forget), breast pain (breast problems in women), swelling (abnormal enlargement of body parts), fetal growth retardation during pregnancy and induction of chromosome loss in in vitro and in vivo. ${ }^{63,64.65,66,67,68,69,70,71}$

A new drug or antitumor antibiotic (11-acetyl-8-carbamoyloxymethyl4-formyl-14-oxa-1, 11-diazatetracyclo $[7.4 .1 .0(2,7) .0(10,12]$ tetradeca-2, 4, 6-trien-6, 9-diyl diacetate, FK973) illustrated tremendous cytotoxic effects on human glioblastoma, medulloblastoma, murine and malignant glioma cells..$^{72}$ The cytogenetic effects such as induction of micronuclei and chromosome breakage at metaphase stage of antitumor antibiotics (carminomycin, doxorubicin and daunomycin) of the anthracycline group were recorded. ${ }^{73}$

Allium Cepa had revealed its potential to measure the geno-mutatoxicity of various drugs in the past. The different concentrations of Alprazolam caused chromosome aberrations and irregular cell cycle in Allium Cepa root tip cells. ${ }^{74}$ The Sao Goncalo Channel water showed increased mutagenic effects on the Allium root tip cells. ${ }^{75}$ The benzo( $\alpha$ ) pyrene induced the chromosomal aberrations in Allium Cepa root tip test. ${ }^{76}$ Benzodiapines (BDZs) or Alprazolam used in medical practice for anxiety disorders (common mental illness such as feeling of uneasiness, worry and fear), panic disorders (sudden attack of fear and panic) and anxiety caused by depression (mental health disorders). Although, the drug has small half-life but gathered and collected nature of the drug was observed in human being. Alprazolam was reported with dose dependent and cyto-carcinogenic effects on Allium root meristematic cells at different concentrations $(1,10,50$ and $100 \mu \mathrm{g} / \mathrm{ml}) .{ }^{77}$ The food preservatives caused the cytogenetic effects on the Allium Cepa root tip meristematic cells. $^{78}$

The cyto-muta-genotoxic effects of metal compounds Ce (III) and Sm (III) in combination with an antibiotic, 3-(2-benzimidazol)-3-nitro-6methyl chromen-4-one were reported on germination, survivality, seedling height and action of spinach (Spinacia oleracea L.) plant.

The plant extract of Azadirachta indica, Alstonia boonei and Carica papaya was an anti-malarial agent and, simultaneously, the anti-malarial drugs, Fansidar and Daraprim was used to observe anti-mitotic effect, if any, on the root tip mitosis of Hippeastrum equestre. Both the plant extracts and anti-malarial drugs had shown the anti-mitotic activity on the root tip mitotic cells. ${ }^{79}$

The agricultural antibiotic, Captan, in the concentration (50, 100, 400, $800,1000 \mathrm{mg} / \mathrm{kg}$ ) range of $50-1000 \mathrm{mg} / \mathrm{kg}$ induced cyto-mutagenetic effects (such as induction of micronuclei, chromosome break, and abnormal sperm morphology) on the mouse bone marrow and testicular cells. The cytogenetic effects were reported for the agricultural antibiotic (Captan) on mouse bone marrow and testicular cells. ${ }^{80}$

The present draft is an effort to consider the consequences of four antibiotics (Cefixime, Metronidazole, Ciprofloxacin hydrochloride, Cefpodoxime proxetil) and one anti allergic (Cetirizine) drug on the root tip mitotic activity of Allium cepa. The drugs are widely used by the common people, sometimes without the prescription of a medical practitioner. The good reason for using these drugs is their easy and extensive use for the treatment of illness. A. cepa has been selected because it has large number of chromosomes $(2 n=16)$, easy to manage the metaphase and other stages, highly thick and easily visible at metaphase stage, moreover, material is easily available in everyone's kitchen.

\section{MATERIALS AND METHODS}

The antibiotics [Cefixime (400mg), Metronidazole (400mg), Ciprofloxacin hydrochloride $(500 \mathrm{mg})$, Cefpodoxime proxetil $(200 \mathrm{mg})]$ and one antiallergic Cetirizine (10 mg) were collected from the market chemist shop of Mokokchung Town, Nagaland. The company make of the antibiotics and anti-allergic is Cipla, Lupin, Alembic, Cipla and Alkem Laboratories LTD respectively.

The different concentrations (ppm) of the antibiotics and anti-allergic medicines were prepared in such a way that the original effective concentrations (400 mg, $400 \mathrm{mg}, 500 \mathrm{mg}, 200 \mathrm{mg}$ and $10 \mathrm{mg}$ ) of the medicines should not be disturbed.

Preparation of different concentrations All the medicines were crushed into a powdered form and used for preparation of different concentrations without change in their effective dose. All the concentrations were made in $100 \mathrm{ml}$ and stored in fridge for further use. The ppm conversion was used to convert $\mathrm{mg}$ into $\mathrm{ppm}(1 \mathrm{ppm}=\mathrm{mg} / \mathrm{L})$. The different concentrations were cefixime and metronidazole (40,80 and $120 \mathrm{ppm}$ ), ciprofloxacin hydrochloride (50, 100 and $150 \mathrm{ppm})$, cefpodoxime proxetil (20, 40 and $60 \mathrm{ppm})$ and cetirizine (1,2 and $3 \mathrm{ppm})$ respectively. The lower concentration $(40,40,50,20$ and $1 \mathrm{ppm})$ of each medicine is equivalent to the effective dose $(400,400,500,200$ and $10 \mathrm{mg})$ of the respective antibiotics and anti-allergic medicines.

Treatment Allium Cepa bulbs were submerged in water at beaker or glass for the growth of the root tips $\left(23 \pm 2{ }^{\circ} \mathrm{C}\right)$ in the laboratory. The root tips were cut when it reached $1-2 \mathrm{~cm}$ long. The root tip meristematic cells were treated with the different concentrations of different antibiotic and anti-allergic medicines for 6,12 and $24 \mathrm{~h}$.

Preparation of slides the root tip meristematic cells were rinsed $(3 \times 5 \mathrm{~min})$ with distilled water. The root tips were fixed in 3:1 (ethanol: acetic acid) fixative overnight in fridge $\left(4^{\circ} \mathrm{C}\right)$. The root tips were rinsed $(3 \times 5 \mathrm{~min})$ and treated with enzyme pectinase $(1 \%)$ for $1 \mathrm{~h}$ at room temperature. The 
tips were rinsed $(3 \times 5 \mathrm{~min})$ and hydrolysed with $\mathrm{HCl}(5 \mathrm{~N})$ for $30 \mathrm{~min}$ at room temperature. The tips were rinsed $(3 \times 5 \mathrm{~min})$ and stained with acetocarmine (2\%) for $15 \mathrm{~min}$. It was squashed on the slide with cover slip and observed under microscope for different mitotic stages and data collection. The data was collected on the different kinds of mitotic stages, total number of mitotic cells, total number of dividing cells, total number of non-dividing cells, number of interphase, prophase, anaphase, telophase, cytokinesis and different abnormal stages such as stickiness, laggards, multipolar anaphase, anaphase bridges and micronucleus. The data was analysed statistically.

\section{RESULT AND DISCUSSION}

\section{Number of mitotic cells Control}

The total number of cells (TNC), number of non-dividing cells (NDC) and number of dividing cells (DC) were counted for three different time $(6,12$ and $24 \mathrm{~h})$, recorded and reported the mean numbers TNC (509.33 \pm 51.42$)$, NDC $(469.67 \pm 54.95)$ and DC $(39.66 \pm 4.25)$ from three different slides Table 1.

\section{Cefixime}

The treatment of root tip cells with cefixime for different h $(6,12$ and $24 \mathrm{~h})$ suggested that TNC were induced and showed a little higher value $(614.67 \pm 19.78)$ over the control at the concentration $(80 \mathrm{ppm})$ and time $(12 \mathrm{~h})$. It seems that the concentration $(80 \mathrm{ppm})$ does not cause in the reduction of total number of cells and, it may not involve in the abnormal function of the cell cycle. But it caused the reduction in total number of cells, when the concentration increased $(120 \mathrm{ppm})$ for $24 \mathrm{~h}$. The increased concentration may have effect on the cell cycle.

The number of NDC has shown the similar trend as the TNC. The NDC increased at $80 \mathrm{ppm}$ for $12 \mathrm{~h}$. It may be involved in the induction of NDC or interphase stages and hence increases the number of NDC over the control. The number of DC were recorded very less in control as compared to the treatment $(320.67 \pm 75.51,110.67 \pm 8.45$ and $184.67 \pm 63.39)$ for all the time which suggest that all the concentration is highly effective in the induction of cell division cycle or mitosis.

\section{Metronidazole}

The metronidazole treatment $(40,80$ and $120 \mathrm{ppm})$ to root meristematic cells indicated very high values $(612.00 \pm 73.02,810.33 \pm 93.26$ and $969.00 \pm 259.52)$ and increasing trend for all the time $(6,12$ and $24 \mathrm{~h})$ as compared to the control. It suggests that the concentrations may be used to increase the TNC by inducing the cell division cycle of the plant but higher concentrations ( 80 and $120 \mathrm{ppm}$ ) equally increasing the number of NDC $(710.33 \pm 89.83$ and $853.33 \pm 217.32)$ as well as DC $(100.00 \pm 20.66$ and $115.67 \pm 52.98)$ over the control.

\section{Cetirizine}

The number of dividing cells (DC) showed higher mean value (53.33 $\pm 11.31,73.33 \pm 10.58$ and $110.67 \pm 60.18)$ over the control at all the concentrations used (1, 2 and $3 \mathrm{ppm})$. It has shown an increasing trend from lower to higher concentrations. The concentrations may cause induction of the mitosis and help to increase the number of dividing cells. Also, it is a good indication to increase the number of cells in human beings suffering from cold and cough where many cells are damaged. It may help in growth and development of new cells or replaced the damaged or torn out cells.

The number of non-dividing cells (NDC) showed higher mean value $(901.67 \pm 40.84)$ over the control at higher concentration ( $3 \mathrm{ppm})$. The concentration is highly effective to induce the non-dividing cells or to stop the cells to enter mitosis. It may be effective at the interphase stage (G1, S and G2) of the cell cycle. The other two concentrations are not effective as they have less value of cells than the control (469.67 \pm 54.95$)$.

\section{Ciprofloxacin}

All the treatment has shown the increasing trend over the control. The concentrations $(50,100$ and $150 \mathrm{ppm})$ were effective to increase the number of cells in terms of TNC $(858.0 \pm 151.40,1033.0 \pm 323.05$ and 694.33 \pm 101.04$), \quad$ NDC $(792.0 \pm 141.30, \quad 628.67 \pm 101.57$ and $628.67 \pm 101.57)$ and DC $(66.0 \pm 11.71,70.66 \pm 0.88$ and $65.66 \pm 5.84)$ than the control $(509.33 \pm 51.42,469.67 \pm 54.95$ and $39.66 \pm 4.25)$, although DC were recorded low in number as compared to the ND and TNC.

\section{Cefpodoxime}

The concentrations (40 and $60 \mathrm{ppm}$ ) showed the effect on the capacity of cell division, the lower concentration (20ppm) does not have much effect. The maximum effect was showed by the concentration $40 \mathrm{ppm}$ which increases the maximum mean value of cells for TNC, NDC and DC. The higher concentration $(60 \mathrm{ppm})$ showed the effect but the number of cells was counted less as compared to the 40-ppm concentration.

\section{Number of mitotic stages \\ Control}

The different mitotic stages [Interphase (I), Prophase (P), Metaphase $(\mathrm{M})$, Anaphase (A), Telophase (T) and Cytokinesis (C)] were observed and mean value from three slides for control $(14.66 \pm 5.78,16.33 \pm 4.09$, $4.00 \pm 1.15,1.00 \pm 0.57,3.00 \pm 2.00$ and $0.33 \pm 0.33$ ) was recorded respectively Table 2 .

\section{Cefixime}

The mean value of all the mitotic stages was recorded higher than the control. The high mean value $(214.00 \pm 58.28)$ of interphase (I) cells were recorded at $40 \mathrm{ppm}$ than $80(26.66 \pm 2.18)$ and $120 \mathrm{ppm}(83.00 \pm 15.53)$. The mean value of prophase was almost constant at all the concentrations but higher than the control. The mitotic stages such as metaphase, anaphase and telophase showed the mixed response, but the mean value was higher side than the control. The maximum cytokinesis $(7.66 \pm 2.90)$ was observed at higher concentration (120 ppm).

\section{Metronidazole}

All the concentrations have shown the decreasing trend in interphase and cytokinesis, but the values are higher side over the control. The mitotic stages $\mathrm{P}, \mathrm{M}, \mathrm{A}$ and $\mathrm{T}$ showed the mixed response and there was no decreasing or increasing trend but mean values are higher than the control.

\section{Cetirizine}

The interphase and prophase cells were not affected by the lower concentration (1 ppm), but higher concentration ( 2 and $3 \mathrm{ppm}$ ) showed increasing

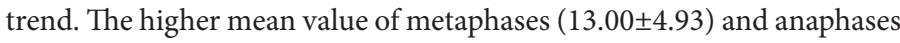
$(4.60 \pm 2.33)$ was recorded at lower concentration $(1 \mathrm{ppm})$ than the control. The higher concentrations ( 2 and $3 \mathrm{ppm}$ ) showed almost constant mean values. Telophase showed mixed response but higher values over the control. the cytokinesis was higher at the high concentration (3 ppm).

\section{Ciprofloxacin}

All the mitotic stages have showed the mixed response at all the concentrations (50,100 and $150 \mathrm{ppm})$. Prophase and metaphase less affected by all the concentrations. The concentrations (50 and $100 \mathrm{ppm}$ ) favours the cytokinesis. 


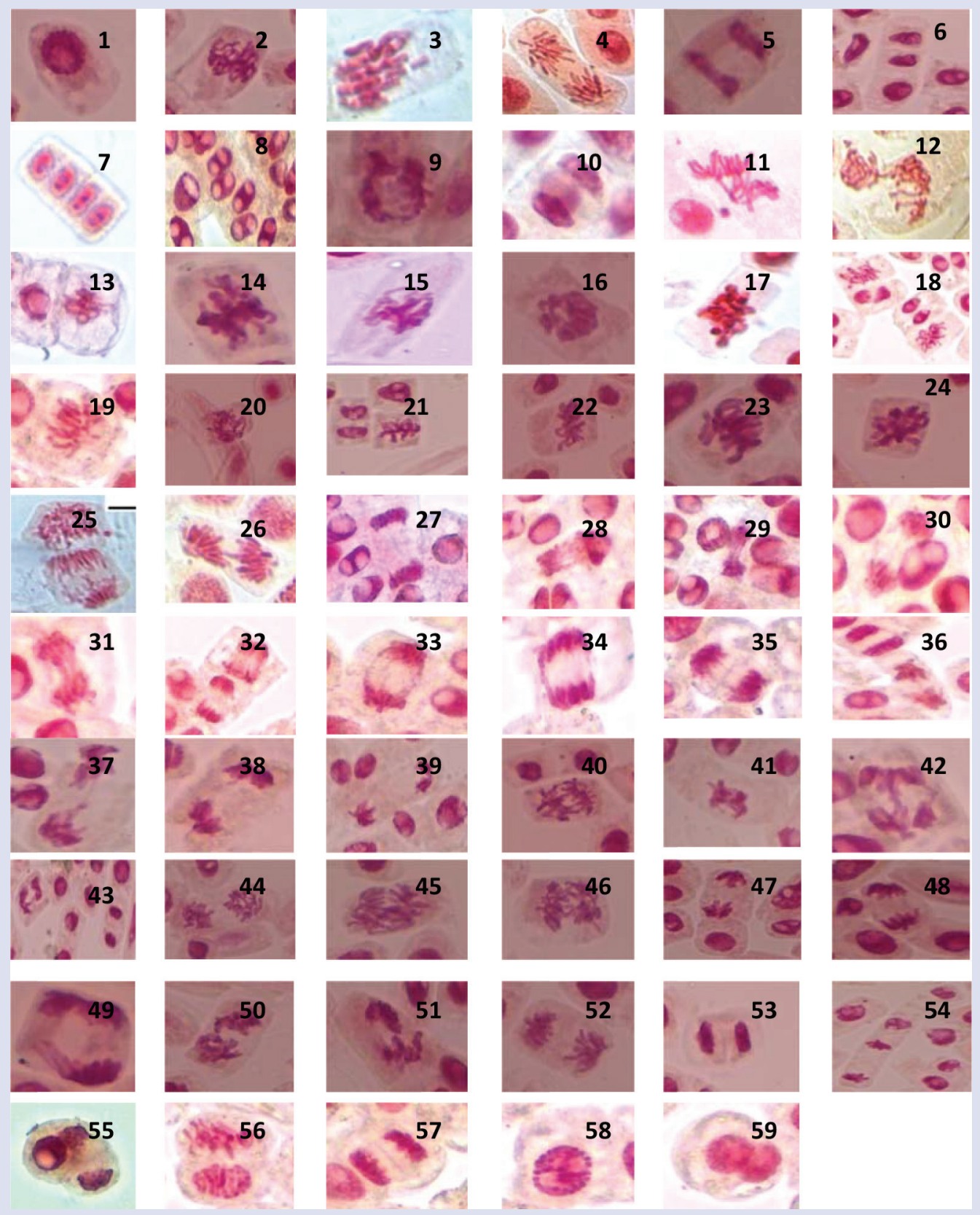

Figure 1: Miotic stages, Control 1-6; Interphase abnormities 7-10; Prophase abnormalities 11-16; Metaphase abnormalities 17-24; Anaphase abnormalities 25-52; Telophase abnormalities 53-55; cytokinesis abnormalities 56-57; others 58-59.

\section{Cefpodoxime}

The concentration (40 ppm) is active and showed good response as compared to the 20 and $60 \mathrm{ppm}$.

\section{Physiological and Clastogenic effects}

The different concentrations of antibiotics were studied for the chromosomal physiological and clastogenic abnormalities and recorded Table 2. The clastogenic abnormalities were recorded for the cefixime as micronuclei $(1.00 \pm 1.00,1.66 \pm 0.80$ and $3.00 \pm 0.57)$, metronidazole as binucleate cells $(1.00 \pm 1.00,1.00 \pm 1.00$ and $1.33 \pm 1.33)$ at all the concentrations (40, 80 and $120 \mathrm{ppm})$, and ciprofloxacin as micronuclei $(0.66 \pm 0.33)$ at lower concentration $(50 \mathrm{ppm})$. The antibiotic cefixime also showed chromosome exchange abnormalities ( $1.66 \pm 0.88$ and $0.66 \pm 0.66)$ at lower and higher concentrations (40 and $120 \mathrm{ppm}$ ). The physiological abnormalities (stickiness, laggards and bridges) were recorded for almost all the antibiotics and at all the concentrations. The other physiological 


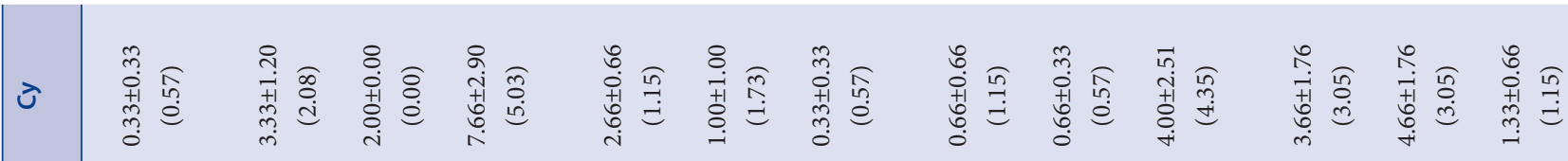

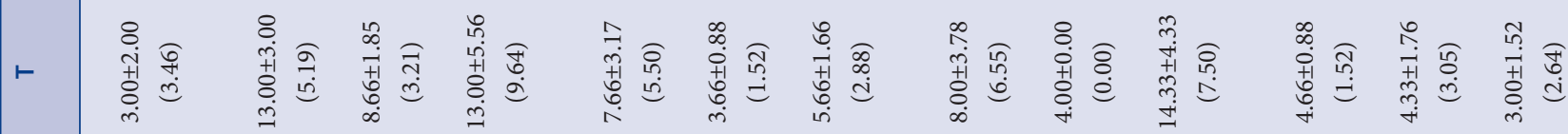

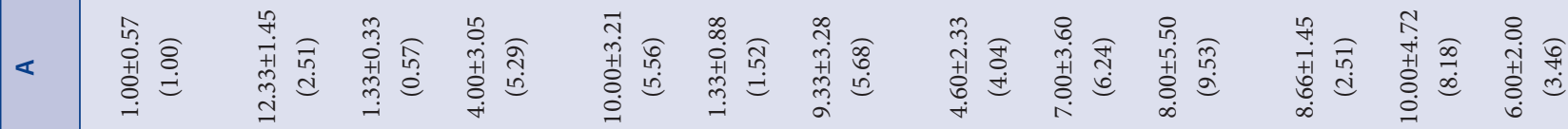

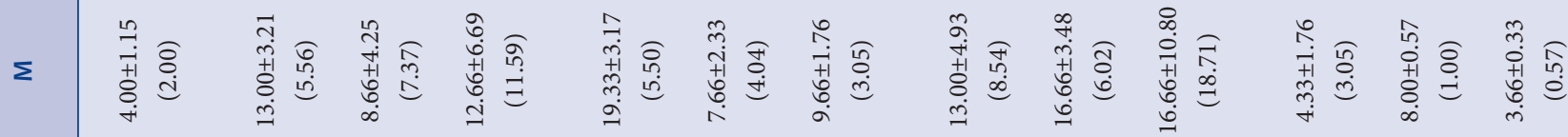

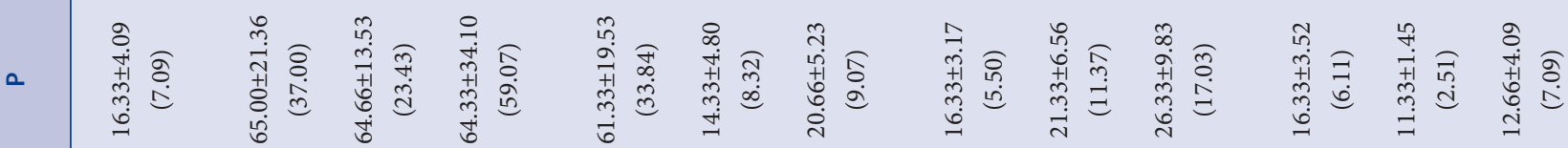

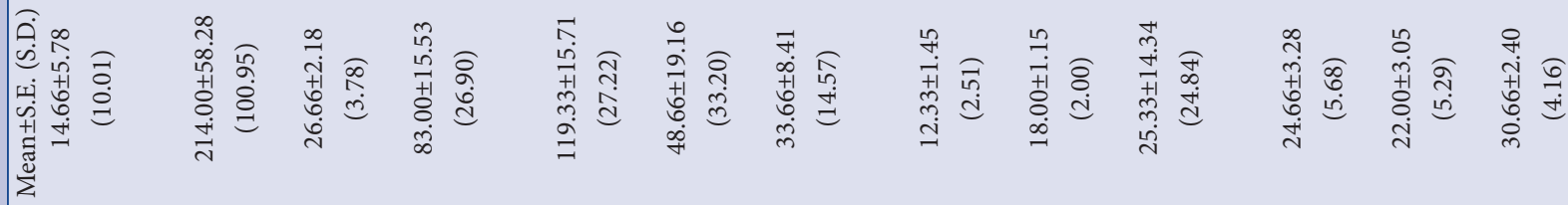

Is

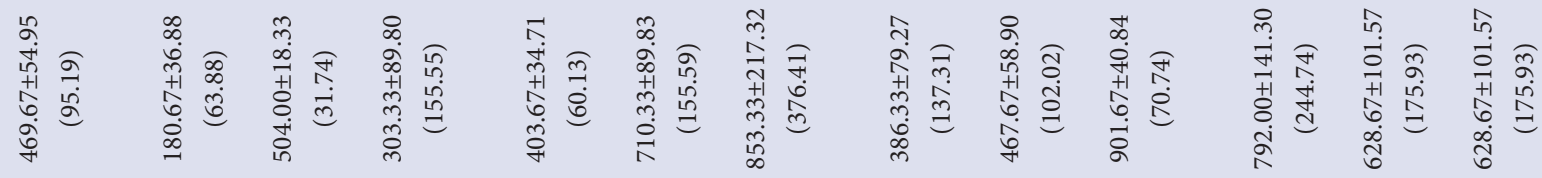

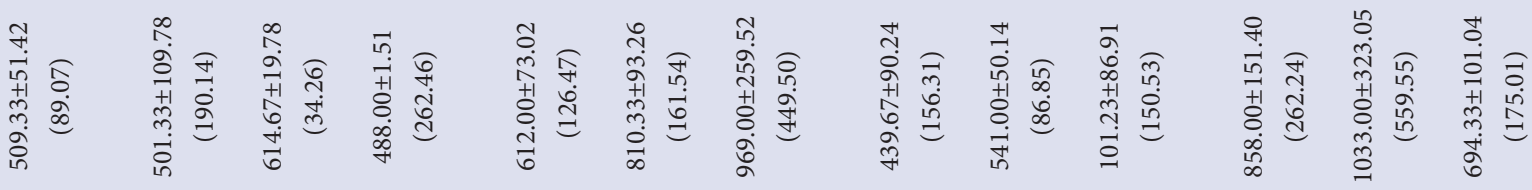

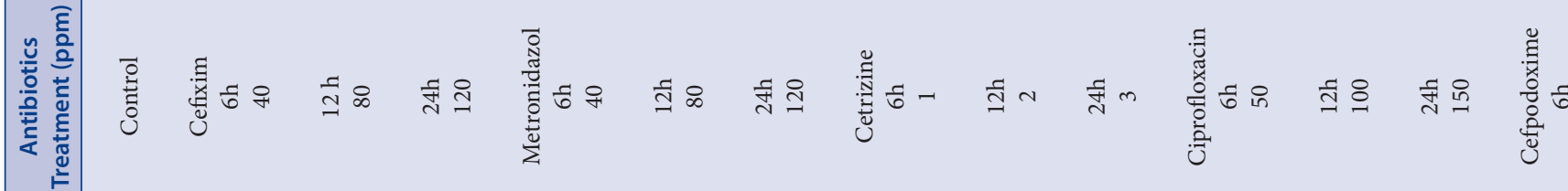



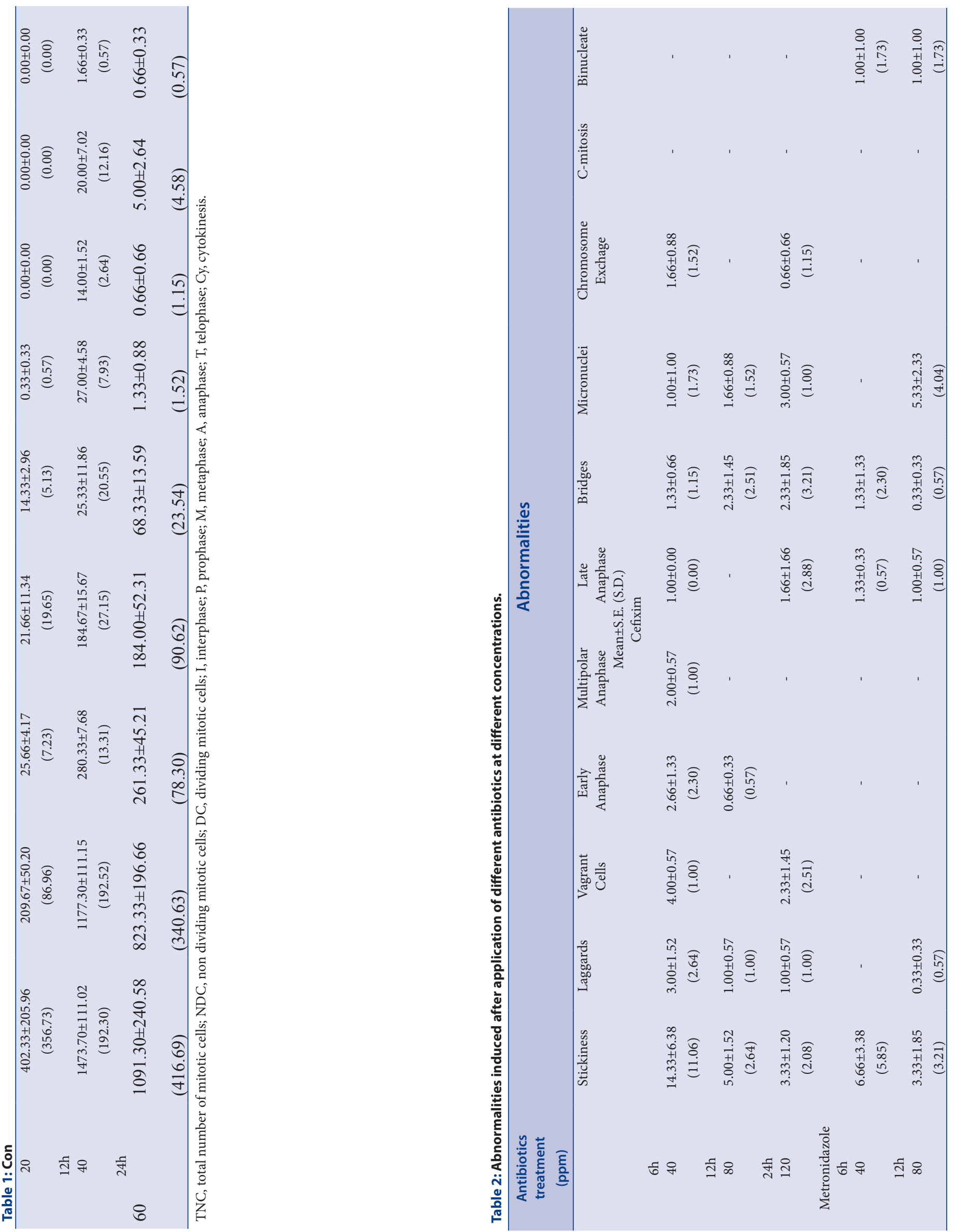


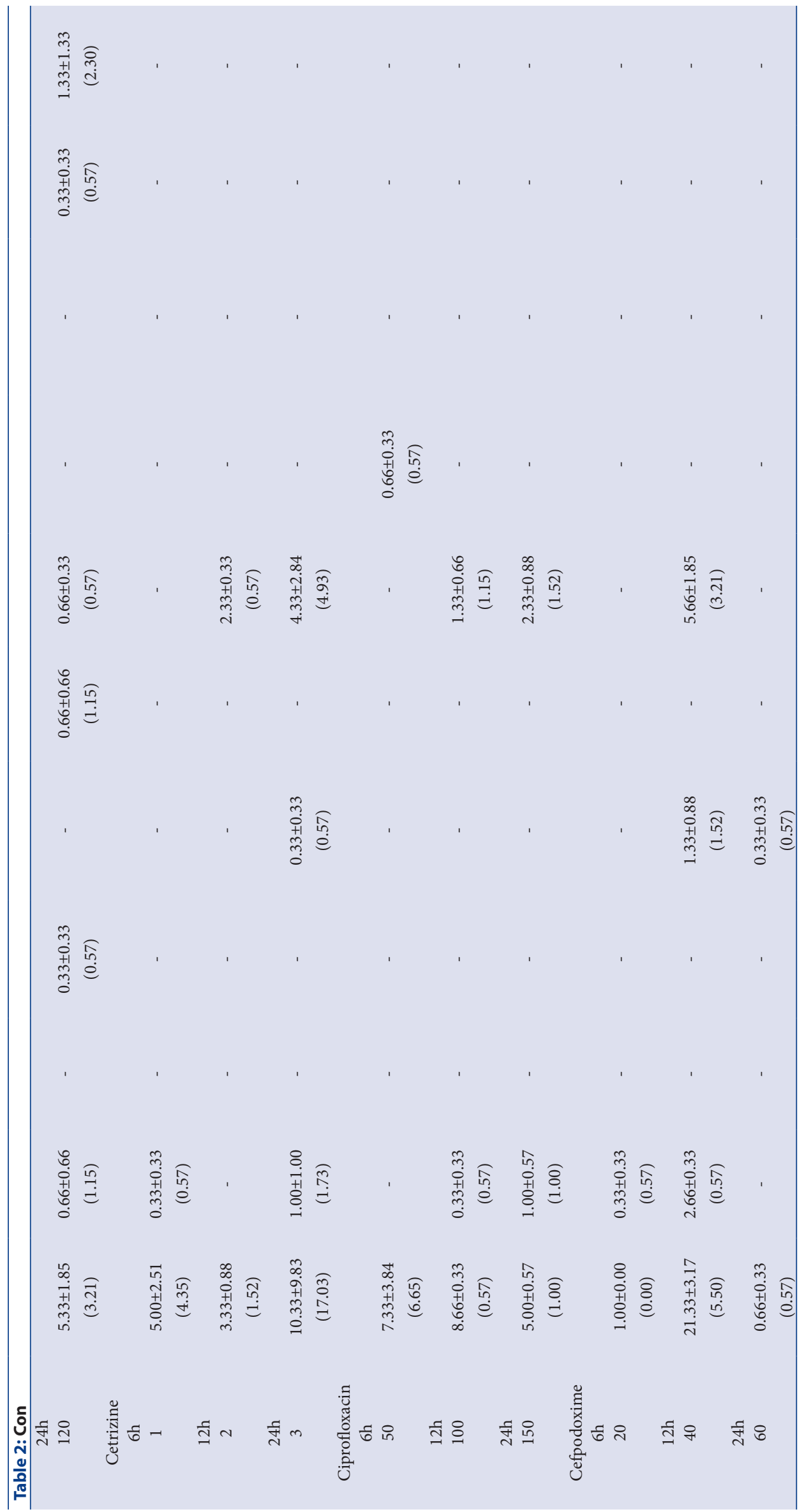


abnormalities were recorded such as vagrant cells, early anaphase, multipolar anaphase, late anaphase and c-mitosis.

\section{Mitotic images abnormalities}

The mitotic image abnormalities induced at different concentrations and time were photographed and reported in Figure 1. The normal mitotic (Interphase, Prophase, Metaphase, Anaphase, Telophase and Cytokinensis) images Figure 1-6, interphase (binucleate cells, interphase nucleoli, nuclear chromatin and interphase chromatin) abnormalities Figure 7-10, prophase (interlaced chromatin, micronucleus, intermingled, looplike structure, sticky, ring like structure, disturbed sticky) abnormalities Figure 11-16, metaphase (disturbed, micronuclei, sticky, interlaced, sticky equatorial and intermingled) abnormalities (17-24), anaphase (fragments, bridges, sticky, loose chromatids, chromatids dissolved type, bipolar at both poles, bipolar at one pole, multipolar, intermingled and dysjunct) abnormalities (25-52), telophase (telocytokinesis, telocytomixis, telocytonucleomixix) abnormalities (53-55), cytokinesis (cell notch, cell plate) abnormalities (56-57) and other (nuclear membrane granules, nucleomixis) abnormalities (58-59) were recorded.

\section{CONCLUSION}

All the doses are potent to induce the mitotic images disturbances and lead to different kinds of abnormalities.

Although the mean value recorded for the abnormalities showed a mixed response and the values are very less to predict the dose response curve. The antibiotics cefixime, metronidazole and ciprofloxacin could not be recommended at higher doses and for longer duration as it may damage the genetic constituent of the plant as well as animals.

\section{ACKNOWLEDGMENT}

The author (Sanjay Kumar) thankful to the M.Sc. (Botany) dissertation students who worked on certain parameters using antibiotics, which led to the design of this article.

\section{CONFLICT OF INTEREST}

Author declare no conflict of interest.

\section{ABBREVIATION USED}

Ppm: Parts per million; DC: Dividing cells; NDC: non dividing cells; TNC: Total number of cells.

\section{REFERENCES}

1. Leekha Surbhi, Terrell Christine L, Edson Randall S. General principles of antimicrobial therapy. Mayo Clinic Proceedings. 2011;86(2):156-67.

2. Rollins KE, Varadhan KK, Neal KR, Lobo DN. Antibiotics Versus Appendicectomy for the Treatment of Uncomplicated Acute Appendicitis: An Updated Meta-Analysis of Randomised Controlled Trials. World Journal of Surgery. 2016;40(10):2305-18.

3. Sahu R, Kashyap P. Genotoxic potential of some commonly used antimalarials. A review. International Journal Pharmaceutical Sciences and Research. 2012;3(6):1569-79.

4. Kar S, Kar S. Control of malaria. Nat Rev Drug Discovery. 2010;9:511-2.

5. Nwangburuka CC, Oyelana OA. Cytological effects of chloroquine on root mitosis of Allium Cepa (L) Actasatech. 2011;4:25-35.

6. Farombi EO. Genotoxicity of chloroquine in rat liver cells: Protective role of free radical scavengers. Cell Biology Toxicology. 2006;22(3):159-67.

7. Roy LD, Mazumdar M, Giri S. Effects of low dose radiation and vitamin C treatment on chloroquine-induced genotoxicity in mice. Environ Molecular Mutagen. 2008;49(6):488-95.

8. Noela S, Sharmaa S, Shankerb R, Ratha SK. Primaquine-induced differential gene expression analysis in mice liver using DNA microarrays. Toxicology. 2007;239(1):96-107.

9. OnoT, Norimatsu M, Yosimura H. Mutagenic evaluation of primaquine, pentaquine and pamaquine in the salmonella/ mammalian microsome assay. Mutation Res. $1994 ; 325(1): 7-10$.
10. Mars TC, Bright JE, Morris BC. Methemoglobinogenic potential of primaquine and its mutagenicity test in Ames test. Toxicology Let. 1987;36(3):281-7.

11. Shubber EK, Jacoson-Kram D, Williams JR. Comparison of the Ames assay and the induction of sister chromatid exchanges results with ten pharmaceuticals and five selected agents. Cell Biology Toxicology. 1986;2(3):379-99.

12. Chatterjee $T$, Mukhopadhyay A, Khan KA, Giri AK. Comparative mutagenic and genotoxic effects of three antimalarial drugs, chloroquine, primaquine and amodiaquine. Mutagenesis. 1998;13(6):619-24.

13. Denny WA. Acridine derivatives as chemotherapeutic agents. Current Med Chem. 2002;9(18):1655-65

14. Clarke JJ, Sokal DC, Cancel AM, Campen DB, Gudi R, Wagner VO, et al. Re-evaluation of the mutagenic potential of quinacrine dihydrochloride dihydrate. Mutation Res. 2001;494(1):41-53.

15. Zipper J, Kessel E. Quinacrine sterilization: a retrospective. Inter J Gynaecology and Obstet. 2003;83:S7-11.

16. Krishnaja AP, Chauhan PS. Quinacrine dihydrochloride, the nonsurgical female sterilant induces dicentrics, rings, and marker chromosomes in human peripheral blood lymphocytes treated in vitro: a preliminary report. Mutation Res. 2000;466(1):43-50.

17. Galloway SM. Cytotoxicity and chromosome aberrations in vitro: Experience in industry and the case for an upper limit on toxicity in the aberration assay. Environ Molecular Mutagen. 2000;35(3):191-201.

18. Kiskinis E, Suter W, Hartmann A. High throughput comet assay using 96-well plates. Mutagenesis. 2002;17(1):37-43.

19. Gasc AM, Sicard AM. Genetic Studies of acridine-induced mutants in Streptococcus pneumoniae. Genetics. 1978;90(10):1-18.

20. Xamena N, Creus A, Velazqez A, Marcos R. Testing of chloroquine and quinacrine for mutagenicity in Drosophila melanogaster. Mutation Res. 1985;158(3): 177-80.

21. Leduc EH, Bernhard W, Viron A, Fain J, Puvion E. Effect of quinacrine on nuclear structure and RNA synthesis in cultured rat hepatocytes. Cancer Res. $1981 ; 41(7): 2832-41$

22. Othman OE, El-Rafey GA, Hassan TA. Cytogenetic and Hematological effects of the antibiotic Chloramphenicol on Calves. Cytologia. 2005;70(1):79-86.

23. El-Mofty MM, Abdelmeguid NE, Sadek IA, Essawy AE, Aleem EA. Induction of leukaemia in chloramphenicol-treated toads. East Mediterranean Health. J. 2000;6:1026-34

24. Turton, JA, Andrews CM, Havard AC, Williams TC. Studies on the haemotoxicity of chloramphenicol succinate in the Dunkin Hartley guinea pig. Inter $\mathrm{J}$ Experimental Pathology. 2002;83(5):225-38.

25. Ikbal M, Dogan H, Odabas H, Pirim I. Genotoxic evaluation of the antibacterial drug, ciprofloxacin, in cultured lymphocytes of patient with urinary tract infection: an experimental study. Turk J Med Sci. 2004;34(5):309-13

26. Weyers Al, Ugnia LI, Ovando HG, Gorla NB. Ciprofloxacin increases hepatic and renal lipid hydroperoxides levels in mice. Biocell-Mendoza. 2002;26(2):225-8.

27. Ambulkar PS, Ghosh SK, Ingole IV, Pal AK. Genotoxic and cytotoxic effects of antibacterial drug, ciprofloxacin, on human lymphocytes in vitro. Nepal Med Coll J. 2009;11(3):147-51.

28. Itoh T, Mitsumori K, Kawaguchi S, Sasaki YF. Genotoxic potential of quinolone antimicrobials in the in vitro comet assay and micronucleus test. Mutation Res. 2006;603(2):135-44.

29. Dalhoff A, Shalit I. Immunomodulatory effects of quinolones. Lancet Infect Dis 2003;3(6):359-71.

30. Vijayalaxmi KK, Vishalakshi M. Evaluation of the genotoxic effects of pyrimethamine, an antimalarial drug, in the in vivo mouse. Teratogenesis, Carcinogenesis, Mutagen. 2000;20(2):65-71.

31. Tunca B, Egeli U, Aydemir N, Cecener G, Bilaloglu R. Investigation of the genotoxic effect in bone marrow of Swiss albino mice exposed long-term to pyrimethamine. Teratogenesis Carcinogenesis Mutagen. 2002; 22(6):393-402.

32. Aydemir N, Celikler S, Bilaloglu R. In vivo evaluation of the toxic effects of pyrimethamine on spermatogenesis in male mice. J Environ Pathology Toxicology Oncology. 2008;27(4):287-93.

33. Ono $\mathrm{T}$, Yoshimura $\mathrm{H}$. Analysis of micronucleus induction of pyrimethamine in in vitro $\mathrm{CHL}$ cells and in in vivo mouse bone marrow cells. Mutagenesis. 1996;11(1):85-8

34. Egeli U, Aydemir N, Akpınar G, Cimen C, Ergul E, Tutar G, et al. In vivo dominant lethal effect of pyrimethamine in male mouse germ cells. Mutagenesis. 1999;14(1):67-9

35. Tsudaa S, Kosakaa Y, Matsusakaa N, Sasakib YF. Detection of pyrimethamine-induced DNA damage in mouse embryo and maternal organs by the modified alkaline single cell gel electrophoresis assay. Mutation Res. 1998;415(1):69-77.

36. Abou-Eisha A, Afifi M. Genotoxic evaluation of the antimalarial drug, fansidar, in cultured human lymphocytes. Cell Biology Toxicology 2004;20(5):303-11.

37. Jopling WH. Side effects of antileprosy drugs in common use. Leprosy Rev. 1983;54(4):261-70.

38. Roy B, Das RK. Cytogenetic effect of dapsone, an antileprotic drug, in the mouse in vivo system. Inter J Leprosy Other Mycobacterial Dis. 1988;56:574-9. 
39. McArdle JJ, Sellin LC, Coakley KM, Potian JG, Hognason K. Mefloquine selectively increases asynchronous acetylcholine release from motor nerve terminals. Neuropharmacology. 2006;50(3):345-53.

40. Okerele JO, Obaseiki-Ebor EE. Studies on the genotoxic and mutagenic potentials of mefloquine. Trop J Pharm Res. 2002;1(2):91-8.

41. Labro MT, Chevaye CB. Effects of amodiaquine, chloroquine, and mefloquine on human polymorphonuclear neutrophil function in vitro. Antimicrobial Agents Chemotherapy. 1988;32(8):1124-30.

42. Karbwang J, White NJ. Clinical pharmacokinetics of mefloquine. Clinical Pharmacokinetics. 1990;19(4):264-79.

43. Bray PG, Ward SA, O'Neill PM. Quinolines and artemisinin: chemistry, biology and history. Current Top Microbiology Immunol. 2005;295:3-38

44. Aquino I, Perazzo FF, Maistro EL. Genotoxicity assessment of the antimalarial compound artesunate in somatic cells of mice. Food Chemical Toxicology. 2011;49(6):1335-9.

45. Mota TC, Cardoso PC, Gomes LM, Vieira PC, Correa RM, Santana PD, et al. In vitro evaluation of the genotoxic and cytotoxic effects of artesunate an antimalarial drug, in human lymphocytes. Environ Molecular Mutagen. 2011;52(7):590-4.

46. Sen R, Bandyopadhyay S, Dutta A, Mandal G, Ganguly S, Saha P, et al. Artemisinin triggers induction of cell-cycle arrest and apoptosis in Leishmania donovani promastigotes. J Med Microbiology. 2007;56(9):1213-8.

47. Willoughby JA, Sundar SN, Cheung M, Tin AS, Modiano J, Firestone GL. Artemisinin blocks prostate cancer growth and cell cycle progression by disrupting Sp1 interactions with the cyclin-dependent kinase-4 (CDK4) promoter and inhibiting CDK4 gene expression. J Biological Chemistry. 2009;23(4):2203-13.

48. Posner GH, O'Neill PM. Knowledge of the proposed chemical mechanism of action and cytochrome p450 metabolism of antimalarial trioxanes like artemisinin allows rational design of new antimalarial peroxides. Accounts Chemical Res. 2004;37(6):397-404.

49. Papis E, Davies SJ, Jha AN. Relative sensitivity of fish and mammalian cells to the antibiotic, trimethoprim: cytotoxic and genotoxic responses as determined by neutral red retention, Comet and micronucleus assays. Ecotoxicology. 2011 20(1):208-17.

50. Binelli A, Cogni D, Parolini M, Riva C, Provini A. Cytotoxic and genotoxic effects of in vitro exposure to Triclosan and Trimethoprim on zebra mussel (Dreissena polymorpha) hemocytes. Comparative Biochemistry and Physiology Part C: Toxicology Pharmacology. 2009;150(1):50-6.

51. Ortiz R, Medina H, Cortes E, Cervantes E, Rodriquez L. Trimethoprim-sulfamethoxazole increase micronuclei formation in peripheral blood from weanling well-nourished and malnourished rats. Environ Molecular Mutagen. 2011; 52(8):673-80.

52. Rocio O, Hilda M, Edith C, Elsa C, Leonor R. Trimethoprim-sulfamethoxazole increase micronuclei formation in peripheral blood from weanling well-nourished and malnourished rats. Environ Molecular Mutagen. 2011;52(8):673-80.

53. Roshdy HM. Cytogenetic and Mutagenic Effects of Levocetirizine and Montelukast alone or in combination on pregnant mice and embryos. Research Journal of Pharmaceutical, Biological and Chemical Sciences. 2015;6(3):979-88.

54. Chuensombat S, Khemaleelakul S, Chattipakorn S, Srisuwan T. Cytotoxic effects and antibacterial efficacy of a 3-antibiotic combination: an in vitro study. J Endodontics. 2013;39(6):813-9.

55. Lanbeck P, Paulsen O. Cytotoxic effects of four antibiotics on endothelial cells. Pharmacology and Toxicology. 1995;77(6):365-70.

56. Brambilla G, Carrozzino R, Martelli A. Genotoxicity and carcinogenicity studies of benzodiazepines. Pharmacology Res. 2007;56(6):443-58.

57. Ibrulj S, Duricic E. Genotoxicity of oxazepam--the micronucleus cytochalasin-B test. Med Archives. 2002;56(2):61-4

58. lakovidou-Kritsi Z, Akritopoulou K, Ekonomopoulou MT, Mourelatos D. In vitro genetoxicity of two widely used benzodiazepines: alprazolam and lorazepam. AUMJ. 2009;36(1):39-44.

59. Jackson CD, Fishbein L. A toxicological review of Beta Adrenergic Blockers. Toxicological Sciences. 1986;6(3):395-422
60. Jangala M, Manche S, Mudigonda S, Raja MK, Sangras BR, Konagurtu V. Evaluation of cytotoxicity of Atenolol in Allium Cepa L. International Journal of Toxicology and Applied Pharmacology. 2012;2(2):18-24.

61. Telez M, Ortiz-Lastra E, Gonzalez AJ, Flores P, Huerta I, Ramirez JM, et al. Assessment of the genotoxicity of atenolol in human peripheral blood lymphocytes: Correlation between chromosomal fragility and content of micronuclei. Mutation Research. 2010;695(1):46-54.

62. Wadworth AN, Murdoch D, Brogden RN. Atenolol A reappraisal of its pharmacological properties and therapeutic use in cardiovascular disorders. Drugs. 1991;42(3):468-510

63. Dumortier J, Guillaud O, Gouraud A, Pittau G, Vial T, Boillot O, Scoazec JY. Atenolol hepatotoxicity: report of a complicated case. Ann Pharmacotherapy. 2009;43(10):1719-23.

64. Kelleher JA. Atenolol-induced breast pain in a woman with hypertension. Ann Pharmacotherapy. 2006;40(5):990-2

65. McGuiness M, Frye RA, Deng JS. Atenolol-induced lupus erythematosus. J Am Academy Dermatology. 1997;37(2):298-9.

66. Gouet D, Marechaud R, Aucouturier P, Touchard G, Sudre Y, Preudhomme JL. Atenolol induced systemic lupus erythematosus syndrome. J Rheumatology. 1986;13(2):446-7.

67. Fragasso G, Ciboddo G, Pagnotta P, Chierchia SL. Septal panniculitis induced by atenolol-a case report. Angiology. 1998;49(6):499-502.

68. Ramanathan M. Atenolol induced memory impairment: a case report. Singapore Med J. 1996;37(2):218-9.

69. Yilmaz MB, Turhan $H$, Akin $Y$, Kisacik $H L$, Korkmaz S. Beta-blocker-induced psoriasis: a rare side effect--a case report. Angiology. 2002;53(6):737-9.

70. Lydakis C, Lip GY, Beevers M, Beevers DG. Atenolol and fetal growth in pregnancies complicated by hypertension. Am J Hypertension. 1999;12(6):541-7.

71. Easterling TR, Carr DB, Brateng D, Diederichs C, Schmucker B. Treatment of hypertension in pregnancy: effect of atenolol on maternal disease, preterm delivery, and fetal growth. Obstetrics Gynecol. 2001;98(3):427-33.

72. Moriuchi S, Shimizu K, Yamada M, Mabuchi E, Tamura K, Park KC, et al. Cytotoxic effects of a new antitumor antibiotic, FK973, in malignant glioma. Anticancer Res. 1991;11(6):2079-84.

73. Novitskii W, Klimova Mlu, Gol'dberg ED. Comparative evaluation of the cytogenetic action of anthracycline-group antitumor antibiotics (daunomycin, doxorubicin and carminomycin). Antibiotic Med biotechnology. 1986;31(10):765-8.

74. Jasmin M, Nerman R, Hilada N, Amela D. Chromosome aberration and irregular cell cycle in Allium Cepa root cells caused by different concentrations of Alprazolam. International Journal of Collaborative Research on Internal Medicine and Public Health. 2013;5(6):407-18.

75. Paiva TS, Garcias GL, Martino-Roth MG. Increasing mutagenicity of São Gonçalo Channel waters based on the Allium cepa test. Genet Molecular Res. 2009;8(1):299-309.

76. Cabaravdic M. Induction of Chromosome Aberrations in the Allium cepa Test System Caused by the Exposure of Cells to Benzo(a)pyrene. Med Archives. 2010;64(4):215-8.

77. Musanovic J, Ramic N, Nefic H, Dzubur A. Chromosome aberration and irregular cell cycle in Allium Ceparoot cells caused by different concentrations of Alprazolam. International Journal of Collaborative Research on Internal Medicine and Public Health. 2013;5(6):407-18.

78. Kumar LP, Panneerselvam N. Cytogenetic studies of food preservative in Allium Cepa root meristem cells. Facta universities - series: Medicine and Biology. 2007; 14(2):60-3.

79. Okagbue RA. Comparative cytological effects of three antimalaria crude plant extract Azadirachta indica, A. jusc, Alstonia boonei, Carica papaya and three synthetic Antimalaria drugs Chloroquine, Daraprim, and Fansidar on the root tip mitosis of Hippeasrtrum equestre. Nig Jor Bot. 1990;7:51-62.

80. Feng JY, Lin BY. Cytogenetic effects of an agricultural antibiotic, captan, on mouse bone marrow and testicular cells. Environ Res. 1987;43(2):359-63. 
GRAPHICAL ABSTRACT

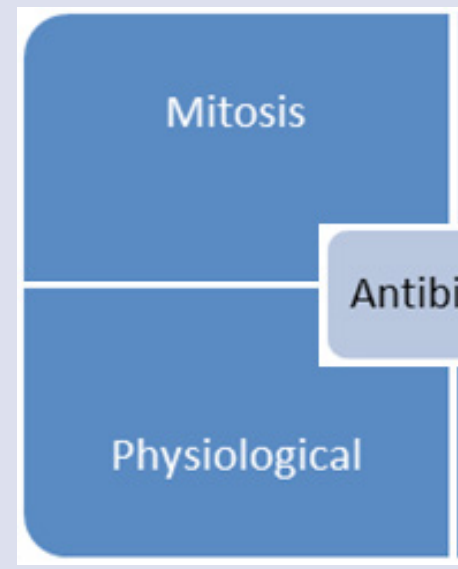

\section{SUMMARY}

- The different concentrations of commonly used antibiotics cefixim $(40,80$ and $120 \mathrm{ppm})$, metronidazole $(40,80$ and $120 \mathrm{ppm})$, ciprofloxacin hydrochloride (50, 100 and $150 \mathrm{ppm})$, cefpodoxime proxetil $(20,40$ and $60 \mathrm{ppm})$ and citrizine (1, 2 and $3 \mathrm{ppm}$ ) applied to root tip cells of Allium and recorded the observations of various forms of abnormalities categorized into physiological and clastogenic which agrees with earlier reports.

- The lower concentration $(40,40,50,20$ and $1 \mathrm{ppm})$ of each medicine is equivalent to the effective dose $(400,400,500,200$ and $10 \mathrm{mg})$ of the respective antibiotics and anti-allergic medicines.

\section{ABOUT AUTHORS}

Dr. Sanjay Kumar has joined Banaras Hindu University recently, earlier he served Nagaland University, Nagaland. He obtained his post-graduation and Ph.D. (Botany) from Banaras Hindu University, Varanasi. His current research interests include Cytogenetics, population genetics, molecular genetics, biochemical and phytochemistry of plants and published many national and international research articles.

Cite this article: Kumar S. Chromosomal Disturbances during Mitotic Activity of Root Tip Cells in Allium by Certain Commonly Used Antibiotics. Pharmacog J. 2018;10(2):355-65. 